\title{
VOTING RIGHTS OF ZIMBABWEANS IN THE DIASPORA
}

\author{
Maurice Taonezvi Vambe \\ Maurice Taonezvi Vambe is a professor in the Department of English Studies at \\ the University of South Africa, Pretoria
}

\begin{abstract}
The Constitution of Zimbabwe states that citizens who have reached the age of 18 years may vote in local and national elections. However, the Electoral Act states that only Zimbabwean citizens who are on diplomatic missions, civil servants and members of the armed forces on external missions may vote from abroad. This legal requirement effectively disenfranchises millions of Zimbabwean citizens who live and work in other countries. Why the current Zimbabwean authorities do not allow or enable their citizens to vote from abroad in Zimbabwe's national elections is contentious, especially ahead of the 2023 general elections. This article uses the desktop approach to argue that the right to vote in one's country of origin by citizens working and living abroad is a barometer of a nation's deepening democratic practices, of which elections are a lynchpin. This study hopes to contribute to international human rights law. A study of voting from abroad contributes to discussions regarding the evolving and multifaceted relationship between sending states and their diaspora communities.
\end{abstract}

Keywords: Zimbabwean citizens, diaspora, voting, Constitution of Zimbabwe, disenfranchising, national elections

\section{INTRODUCTION}

There are increasing debates in international law regarding 'elections and voting in democratic versus authoritarian regimes' (Brand 2010, p. 81). On one hand, citizenship ought to entitle one to vote in the national elections of one's country of origin from anywhere, including abroad. On the other hand, some governments believe that citizens who are not 'directly subject to the implications of their vote should not have the right to participate in determining the composition of representative organs whose decisions are not binding on them' (Nohlen \& Grozt 2000, p. 1136). Despite the above contrasting perspectives on external voting, 
many countries hosting citizens of other countries increasingly consider allowing external voting as the norm (Lacy 2007). According to Baubouk (2005), voting rights are traditionally regarded as the core of democratic citizenship. This view is based on tested assumptions in some parts of Africa where external voting by citizens of one country in the elections of another country cannot be viewed as neutral political space.

In those African states where authoritarian politicians seek to stay in power at all costs, constitutions have been manipulated through restrictive electoral processes and the open rigging of elections (Tungwarara 2013), as well as by the use of 'illegitimate and excessive violence aimed at terrorising people and forcing actual and potential protesters into submission' (Mavungu 2013, p. 25). Undermining the right of citizens in the diaspora to cast their votes attempts to subvert the 'right to vote [which] is a basic pre-condition for preserving other fundamental civil, social and political rights' (Maseko 2010, p. 243). Voting rights distinguish whether people are considered citizens or subjects and refugees (Mamdani 2018). Discriminating between citizens who can vote and those who are denied the right to vote is one of the repressive methods used by authoritarian states to define who belongs to the nation and those marked as being outside the definition of citizenship. Those citizens whose rights to vote from abroad are supressed through legislation may not participate in the politics of the nation state.

In the theory of bounded citizenship, communal and individual citizen rights are linked to a state that 'exerts power over a geophysical territory and grants the individual the capacity to act' (Bankowski \& Christodoulidis 1999, p. 84). This restrictive definition of citizenship curtails and undermines the voting rights of those citizens of one country who are living and working in other countries. Convergence of contemporary legal thought suggests that residence in another country is not a sufficient factor to bar citizens from political participation and voting in the national elections of their countries of origins (Baubouk 2005, p. 683). Since the 1970s, emigrants from Africa had different reasons for moving; these included both pull and push factors such as escaping political persecution and searching for greener pastures. Others were economic refugees, where the notion of transnational identities and citizenship was deliberately promoted by host countries in search of skilled workers. Still others chose to settle in countries of their preference as permanent residents while retaining their citizenship in their countries of origin. These people continued to have powerful cultural links with their countries of origin and often tried to influence political processes in democratising their native countries.

Thus, the voting rights of citizens of one country exercised in host countries are linked with migration; both emigration and immigration expose the people of the diaspora to new experiences that they might take back to their countries of 
origin (Lupoli 2007). Diasporans who remitted money to their countries of origin feel that they need to be accorded the right to vote by their countries of origin. Citizens working abroad pay tax through remitted funds and this is a critical reason why such citizens should be entitled to vote from abroad. Bankowski and Christodoulidis (1999) argue that the idea of 'citizen unbound' means that the membership of individual citizens in a state should emphasise voting rights and equal treatment, as well as governance performance which takes into account citizens' preferences. The real meaning of being a citizen in relationship to voting rights would consist of the capacity and power of citizens to retrieve their voting rights and ensure equal treatment, as well as influence effective decision-making in the polis, from any country of residency. The idea of national identities acquired beyond the borders of one's country of origin shifts perceptions of what constitutes citizenship. It also re-defines the parameters of how and from which geographical territories one should be enabled by legal institutions, and allowed by the laws of the land to vote in national elections. In the theory of expanded citizenship (Baubouk 2005) citizens could be resident abroad and yet continue to contribute politically in their countries of origin.

\section{Diaspora Voting Rights in the EU}

The debates over granting voting rights to non-resident citizens within the EU may be traced to the Maastricht Treaty of 1992. The impetus that informed this treaty arose out of the European Commission report of 1986, which asserted that 'in order for the right to vote to be truly universal, it must be extended to all residents of the territory irrespective of nationality' (Maseko 2010, p. 243). Article 4 of the directive that emerged from the Maastricht Treaty clarified that:

... in order to vote, nationals of the member state of residence must have spent a certain minimum period as a resident in the territory of that state, the non-national EU citizen is deemed to have fulfilled that condition of residence by residing in any other member states for an equal period of time.

Non-resident citizen rights to vote are further emphasised in the 2000 Report of the Committee on Migration, Refugees and Demography on Participation of Immigrants and Foreign Residents in Political life in the Council of Europe Member States, as reiterated in article 34 of the Lisbon Treaty. Furthermore, the rights of non-residents to vote in host countries is also entrenched in the Charter of Fundamental Rights of the European Union (Maseko 2010). Current and positive global trends by countries that have decided to enable their citizens to vote from 
abroad is largely a norm in the EU where firm and robust legal and institutional frameworks allow it, and most of their member states have decided to abide the rules of this new normal.

\section{Diaspora Voting Rights in Canada}

In Canada, the voting rights of non-citizens wishing to vote in their country of residence is justified in the Frank $v$ Canada case. On 11 January 2019, a majority of the Supreme Court Judges of Canada ruled that certain provisions in Canada's electoral law which denied federal voting rights to Canadian citizens who resided outside of Canada for more than five consecutive years, were unconstitutional (McGrade, Cassels \& Graydon 2019, pp. 1-3). It was concluded that

[in a] globalised world many Canadians living abroad have deep political, familial, financial or cultural roots in Canada....and that many laws have extraterritorial application and confer both benefits and burdens on non-resident citizens, including laws with respect to taxation, criminal law, foreign anti-corruption measures, government benefits and citizenship.

\section{Diaspora Voting Rights in Africa}

In contrast, many African states have tended to use the idea of bounded citizenship when determining whether or not to extend voting rights to their citizens working in other countries. Different socio-economic, political and security factors motivate people to move out of their countries of origin and settle in other countries. A major reason for migration in Africa is that nationalist movements fought colonialism using the language of one man, one vote. In addition, after independence it became clear that some nationalist leaders were not interested in upholding the rule of law regarding the people's rights. Coups and countercoups in West Africa, political instability in the Democratic Republic of the Congo (DRC), and the threat of starvation in some countries within the Southern African Development Community (SADC) in the post-independence period, continue to force many people from these regions to move to more economically stable countries.

Fortunately, the African Union (AU), which replaced the OAU in 2000, reaffirms the need to promote and protect people's rights in accordance with the African Charter on Human and People's Rights and other relevant human rights instruments (Constitutive Act of the AU 2000 Article 4d). The African Charter on Democracy and Elections (2007 articles 3(7)) supports 'effective participation of citizens in democratic and development and in governance of public affairs'. 
Article 23(4) and (5) contemplates sanctions on 'any refusal by an incumbent government to relinquish power to a winning party or candidate after free, fair elections, regular elections or any amendment, or revision of the constitution or legal instruments which is an infringement on the principle of democratic change of government'.

The main hurdle to diaspora voting is that the AU regulations on the right of African migrants to vote from abroad are interpreted differently by different African countries. Individual African nations are expected to enforce the actual process that will enable citizens working abroad to vote in national elections. However, the motivation by individual African countries to implement voting by Africans in the diaspora will depend on various factors. These include the political will of the ruling elites and the availability of a 'friendly' legal and institutional framework that simplifies the process and legal requirements to vote from abroad.

Implementation of the diaspora right to vote from abroad in the national elections of their native countries is unevenly applied across African countries. Botswana, Mozambique, Senegal, and South Africa allowed and then implemented diaspora voting for presidential elections in 1997, 1993 and 1994 respectively (The International IDEA Handbook: Voting from Abroad 2007, pp. 233-245). Emerging democracies in Africa deliberately put in place legislation that enabled their citizens to vote from where they were living and working. Kenya, for example, allowed the registration of eligible diaspora voters to cast their votes in the Kenyan presidential elections of 26 October 2017. However, this was initially limited to only those Kenyan citizens in some East African countries (Burundi, Rwanda, Tanzania and Uganda) and South Africa (Akwei 2017). While this important development is a step in the right direction of enhancing electoral reform and as such is likely to deepen democracy in Kenya, that country needs to extend its electoral reform to enable more Kenyan citizens to vote from abroad.

Lesotho, Uganda and Zimbabwe have not yet allowed their increasing numbers of citizens in the diaspora to exercise their right to vote from abroad. The ability to vote from abroad by citizens in Lesotho, Uganda and Zimbabwe is currently confined to state officials at foreign embassies. This lacuna in the experiences of African citizens to vote from the host countries where they live and work, means that some African countries have yet to recognise its citizens with full voting rights that authorities should respect. For the majority of the citizens in these countries the ability to vote in presidential elections is determined by whether or not the citizens have satisfied certain legal requirements as stipulated in the electoral laws of these countries. Many of these legal requirements appear calculated to discourage and disallow citizens in the diaspora to vote in national elections in their native countries.

The legal requirements that might enable African diaspora populations to vote from abroad tend to be restrictive for African migrants who have become 
permanent residents in their host countries. The restrictions arise from the constraints imposed on migrants because of the time spent travelling back to their country of origin to vote. Most Africans in the diaspora perform menial jobs that do not enable them to save enough money to return home to vote. Perhaps, and most importantly, it is difficult to satisfy the legal provisions that determine eligibility to vote as being based on several years of proven continuous domicile at a recognisable single address in their native countries. Even if this legal requirement could be satisfied, most African migrants in foreign lands are likely to retain their work rather than opt to take leave in order to vote back home. Of the many African migrants in the diaspora, very few are prepared to risk losing their jobs in host countries where competition for jobs is intense. Taking all these factors into account, it is likely that many African migrants who are resident in other countries lose their right to vote in the general elections in their countries of origin. As a result, African migrants are denied the right to participate meaningfully in the political processes that might lead to the re-shaping of better futures for their countries of origin.

\section{Diaspora Voting Rights in SADC countries}

As mentioned above, South Africa and Botswana provide examples of SADC member states that do allow their citizens working in other territories to vote in national elections. In South Africa, for instance, the rationale for allowing citizens who are resident in other member states to vote in national elections was established in the Richter $v$ Minister for Home Affairs and Others case in 2009. The court identified the link between economic integration, voting rights and the need to create a shareable political culture as inseparable. In addition, non-resident South African citizens were viewed as possessing valuable experiences that they could use through the exercise of their voting right in ways that could reshape South Africa in positive directions that would deepen the country's democratic agenda. In Richter v Minister for Home Affairs and Others, the court observed that:

... we now live in a global economy which provides opportunities to South African citizens and citizens from other countries to study and work in countries other than their own. The experience that they gain will enrich our society when they return, and will no doubt enrich, too, a sense of a shared global citizens... to an extent that citizens engaged in such pursuit want to take the trouble to participate in elections while abroad, it is an expression both of their continued commitment to our country and civic mindedness from which our democracy will benefit. 
This view promotes active participation in the national elections of the country by South African citizens who are resident abroad. Self-rule recognises that sovereignty is shared and that transnational identities forge new forms of citizenships. This means that community citizenship should be viewed as one that contests its own political space in order to question the idea of fixing citizenship within the territorial boundary of a single country. To reiterate, allowing citizens who are resident abroad to vote in national elections of their countries of origin is a form of acknowledging that sovereignty is shared between member states.

This acknowledgement in some countries within the SADC underlines the significance of transitional justice in the context of deepening democratic and electoral processes. These forms of good practice in regional governance also strengthen the countries' human rights-oriented institutions in the countries where this is practised. In other words, some SADC countries such as South Africa and Botswana that have implemented legal and institutional frameworks to allow their citizens to vote from abroad, are better placed to establish supranational institutions that can play the vital role of oversight to ensure that human and people's rights to vote are recognised and respected.

\section{ZIMBABWE}

The disturbing questions that engage the balance of this study are: Firstly, why has Zimbabwe not embraced transparent electoral practices to allow all the country's citizens working and living abroad to vote when this is increasingly becoming a norm in SADC? Secondly, what challenges does Zimbabwe face which deny her diasporic citizens, such as refugees and economic migrants, the right to vote from abroad? These questions are important and should be posed not only because Zimbabwe is scheduled to have another general election in 2023; citizen participation in the affairs of their country of origin is a critical barometer of deepening democratic practices. In the context of the development of international human rights law, it does not seem reasonable to exclude expatriate citizens and refugees from voting from abroad because many of these social groups might be 'keen to return in the future and their chances of doing so may be heavily on political changes in their countries of origin' (Mandal 2003, p. 4).

The issue is not the right to vote when one returns home, which Zimbabwe allows, but the right to cast a vote from abroad. In discussing these questions this study uses an interdisciplinary theoretical approach ranging from the legal and institutional framework and the power of ideological interests to the political perspectives of those in authority. The objective is to understand why Zimbabwean politicians would want to remain in power at the expense of democratic institutions that should open up elections to all citizens (Moyo 2013; 
Mavungu 2013). According to Chigara (2018) some conservative scholars would prefer those questions not to be posed. However, other more progressive scholars welcome the questions because Zimbabwe's commitment to democracy, free and fair elections and good governance is complicated by the military coup of 17 November 2017 that effected an unconstitutional change of an elected government. What is already known openly by many Zimbabweans, both local citizens and those abroad, is that on 17 November 2017 the incumbent president of Zimbabwe, Mr Emmerson Mnangagwa, was propelled to power through a military coup (Asuelime 2018; Zimbabwe Human Rights Report 2018). After the controversial elections of 30 July 2018, the same military protecting the incumbent president shot and killed some of the demonstrators protesting against the failure of the Zimbabwe Election Commission (ZEC) to announce the election results of their preferred candidates (Goredema 2019). Neither SADC nor the AU spoke out against the Zimbabwe coup (Chigara 2018; Saurombe 2019).

\section{Diaspora Voting Rights in Zimbabwe}

In its founding values, the Constitution of Zimbabwe Amendment (No 20) ACT 2013. s3, Founding Values and Principles, subsection 2(a-c)) states that the electoral system is based on universal adult suffrage and equality of votes; free fair and regular elections; and adequate representation of the electorate. However, there is a selective interpretation of the Constitution on who fits the definition of a Zimbabwean citizen. This is so because '...the current Zimbabwean laws permit external voting for Zimbabweans through postal voting. However, that right is limited to citizens that are outside the country while in the service of the state such as diplomats, civil servants and members of the armed forces' (Moyo 2013, p. 6).

The link between which types of citizens can exercise their right to vote, where, and how, is clarified in the Zimbabwe Electoral Act 2 p. 13. Part V of the ACT S (23) requires that citizens must satisfy the residence qualification, which means that the aspirant voter must have lived in Zimbabwe at that location or address for not less than twelve months. Zimbabwean citizens in the diaspora who can vote from abroad are restricted to those in the diplomatic corps, or government officials on official duties outside the Zimbabwean territory. This restriction effectively denies Zimbabwean citizens working abroad the right to vote. Zimbabwe has more than three million people in different southern African countries, and nearly a million of its citizens in the UK, North America and other countries outside Africa (Mandal 2003). This means that millions of Zimbabwean citizens in the diaspora may not vote in Zimbabwe's national elections.

Section (23) of the Electoral Act suggests that even for citizens resident in Zimbabwe the right to vote is not absolute but conditional. Zimbabwean citizens domiciled in the country qualify to vote 'Subject to this Constitution'. 
Moyo (2013, p. 4) points out that this phrase suggests that citizens' rights to vote are limited, and further identifies a contradiction introduced by this legal proviso when he argues that:

When one considers that the right to vote was at the core of the struggle for independence, and adult suffrage is such a universally recognised right, one would expect it to be one of the most absolute rights from which there should be no derogation whatsoever.

The struggle for political freedom that was a major aspiration of nationalist movements did not contemplate all the complexities implied by the term citizen. This is the reason why questions of social identity based on class, racial, gender and age differences often play themselves out openly and violently during and after independence (Krieger 1995). The definition of citizen was underplayed during the armed struggle in favour of an imagined collective national identity. However, as Chimedza (2008) argues, after 1980 citizenship became a contested issue and a more visible site of struggle. In contrast, Constituteproject.org (2021), a pro-Zanu-PF organisation, believes that an argument can be made that the silence in the Constitution on the critical matter of voting by a critical mass of Zimbabwean citizens does not in and by itself undermine voting rights of the people in the diaspora. It is politicians who give life to a piece of legislation through amendments. It thus appears that the possibility of transnational citizenship continues to be subverted by Zimbabwean authorities who seem to insist on bounded citizenship as the main qualification for participation in the political affairs of the country.

\section{Restrictions on Diaspora Voting Rights in Zimbabwe}

From a legal point of view, it might be argued that the reasons for denying Zimbabweans in the diaspora the right to vote are found in the judgement of the Shumba and Others Vs the Ministry of Justice, Legal and Parliamentary Affairs and Others (2018). However, there may be other important reasons why non-resident citizens of Zimbabwe are denied their right to vote from the adopted countries where they now work and live. Odok (2019) has argued that although Zimbabwe's independence was gained after a protracted armed struggle in which the elites and the masses had different roles, the armed struggle itself was shaped by authoritarian and totalitarian tendencies. Zimbabwean leaders from Zanla and Zipla, the two armed wings of the struggle, were trained politically in China and the former Soviet Union, neither of which could be described as democratic societies. Odok argues that the repressive tendencies learnt from these countries 
infiltrated the political ideologies of Zimbabwe's leaders who view Zimbabwean citizens abroad as sell-outs and not citizens.

Estimates of the number of Zimbabweans living in the diaspora vary widely, but it is probably between two and four million. This means that any of the political parties in Zimbabwe could benefit from Zimbabwe's diasporan vote. However, most politicians from Zanu-PF view Zimbabwean citizens in the diaspora as '... [an] unpatriotic, angry and less engaged group' (Murithi \& Mawadza 2011, p. 4). When citizens abroad are labelled unpatriotic, it is unlikely that ZanuPF's political matadors will enable these citizens abroad to vote in the country's national elections due in 2023 (DFAT Country Information Report Zimbabwe 2019). Zimbabwe's citizens in diaspora are further described as an angry social group by their own leaders in Zimbabwe, which might mean they fear that these citizens might become 'irrational' and vote for the opposition political parties. This assumption homogenises the political affiliations of Zimbabwean citizens in the diaspora.

Zimbabweans in the diaspora have multiple affiliations to Zimbabwe, and their personal views of their status as citizens of Zimbabwe are enhanced and not diminished by working and living in other countries (Nyamnjoh 2007). Citizens in the diaspora are a 'heterogeneous social groups [with] differentiated diasporan identities, connections claims, like those of many other groups, [that] are often fluid and contested changing over time and space' (Muzondidya 2011, p. 113). This perspective offers a reason for Zimbabwean authorities not to extend voting rights to those Zimbabweans living abroad. In addition, the economic role of Zimbabweans in the diaspora in keeping Zimbabwe's economy afloat during the near-total collapse since 2000 continue to be minimised by Zanu-PF leaders to create the false impression that the diaspora vote is inconsequential to running Zimbabwe (Mandela Institute for Development Studies 2018; African Commission on Human Rights 2015, p. 29). For example, demeaning public statements by government officials in Zimbabwe describe the work performed by Zimbabweans in the diaspora as that of 'British bottom cleaners' (Madziva, McGrath \& Thondhlana 2013, p. 1).

Zimbabwean leaders have also used extra-legalistic means to deny universal suffrage to the majority of Zimbabweans in the diaspora. According to Hlatshwayo and Mangongera (2020, p. 7), after the military coup of 2017 social movements for justice were terrorised by the security sector as President Mnangagwa 'retained the systems that Mugabe sustained, namely a captured judiciary, biased state media, draconian laws, repression and ... a partisan security sector'. After 2017, a military-led government showed little political will to offer Zimbabweans in the diaspora the opportunity to exercise their right to vote from abroad. External voting is still limited to the government's functionaries who are resident in other countries (Constitution of Zimbabwe 2013). In a meeting with the Zimbabwean 
community in Namibia, President Emmerson Mnangagwa defended his administration's refusal to accord Zimbabwean citizens in the diaspora their right to vote from that country. He argued that Zimbabwe had insufficient funds, and also lacked adequate human and material logistics and capacity to enable diaspora voting in 2018 (AmsterdamNews 2018). Moyo (2013, p. 3) adds that:

The question of diaspora voting is usually presented as a matter of principle, based on the universality of the right to vote. In reality, however, the practice of such a right is enabled by legislation and procedures put in place by politicians. Politicians, by definition, are partisan individuals whose first interests are for the party they represent. The fact that such a right has to be made possible by politicians who will first consider the impact of such a law on the future of the party leads to legislators, more often than not, disabling that right for the diaspora. Such disablement is premised on the untested belief that the diaspora will mostly vote for the opposition parties (in cases where the ruling party is the reason why such people are in the diaspora).

This view suggests that Zanu-PF politicians calculated that giving the diaspora the right to vote might undermine their rule, a view shared by Bertelsmann Stiftung (2018, p. 36) which argues that 'Zanu-PF's rhetorical support for democracy is put into practice only as long as its hold on power is not endangered by elections'.

\section{Why the Zimbabwean Diaspora Lacks Robust Cohesion}

In identifying different categories of Zimbabwe's diaspora that lack a common shared perspective on the issue of their voting rights, Kuhlmann (2010, p.12) observes that:

Even though the main and most visible activism is human rights and opposition activism, diaspora politics include various different voices and there are also political activists with different political agendas such as anti-opposition and government supporters, tribal secessionist activism and an ominous 'Rhodesian lobby' which, however, do not operate as much in the public sphere as the human rights and political opposition activist do.

His study shows that the Zimbabwe Vigil and Free Zimbabwe Youth engage in street demonstrations. This is opposed to 'Epistemic members such as 
NewZimbabwe.com and ChangeZimbabwe.com' (ibid.) who debate the economic future of Zimbabwe using online platforms. Furthermore, Kuhlmann also discusses what he calls the 'dormant members' (ibid.) of the Zimbabwe diaspora, whom he says are inactive as they fear the long reach of Zimbabwe's dreaded secret services. Amongst Zimbabwe citizens in diaspora there is also the fear of unpredictable behaviour by host countries who can report Zimbabwe citizens' activities to Zimbabwe, and even deport them back to Zimbabwe. Some members of the Zimbabwe diaspora may not wish to be identified as Zimbabwean, although they have taken new identities such as Zimbabwe-South Africans (Kuhlmann 2010, p. 13).

As Pasura (2008) has also noted, these views suggest that the Zimbabwe diaspora community is a dynamic but also a fragmented community. The critic suggests that not all the different social groups of the Zimbabwean diaspora appear to think that the struggle for the right to vote is central to their lives. This means that the repressive politics within the territory of Zimbabwe (Makumbe 2009) and 'variable patterns of constraints, and controls of opportunities' (Esman 1992 , p. 3) by host countries appear to conspire against a solid organisation of the Zimbabwean diaspora to speak with a single voice. These arguments acknowledge the ambiguities and social differentiations within the diaspora social group. The Zimbabwe government has tended to take advantage of this social fragmentation to enable its state officials not to feel obligated to include a provision in the Constitution that accords the right to vote for Zimbabwe's diaspora. Other scholars point to the weak structures of civil society in Zimbabwe as contributing to the lacklustre attitude towards according the Zimbabwe diaspora the right to vote from abroad (Vambe 2019).

\section{Why Opposition Political Parties Appear Reluctant to Promote Diaspora Voting from Abroad}

Opposition political parties in Zimbabwe could be expected to canvass for political votes that might be cast in their favour by Zimbabwean citizens working abroad. This expectation is grounded on the popular assumption that Zimbabwean citizens in the diaspora were forced out of Zimbabwe overtly or covertly by the failures of Zanu-PF's economic policies, and the outright political persecution of some dissenting voices (Chari 2017, p. 84). However, in 2009 Tendai Biti (then a senior member of the MDC-T) and finance minister under the Government of National Unity (GNU) between Zanu-PF and MDC-T, blocked the diaspora vote by proposing that Zimbabwean citizens in the diaspora would have to pay taxes to the Zimbabwean government in return for the right to vote from their adopted countries of residence (Oliver 2009). Zimbabwean citizens in the diaspora felt that this was an uncharitable demand. According to Ryhove (2013, p. 4), 'rights 
do not cease to be rights simply because they have not yet been confirmed by legal processes'. The Zimbabweans in the diaspora argued that the right to vote is a fundamental right that ought not to be exchanged for political expediency.

Between the years 2000 and 2013, Zimbabwean citizens in the diaspora were already burdened by remittances they sent to their families. They were largely responsible for enabling Zimbabwe to remain financially afloat in a global environment where foreign direct investment had dried up due to the West's response to Zimbabwe's chaotic land reform. However, as Tungwarara observed (2007, p. 57), 'despite increasing demands, the government maintains that it has no obligation to introduce external voting arrangements to allow the growing numbers of Zimbabweans living outside to the country to vote'. Therefore, Biti's proposal for the Zimbabwean citizens in the diaspora to accept the condition to pay or remit tax to Zimbabwe in exchange for voting in the country's national elections in the diaspora was not welcomed by Zanu-PF, MDC-T and some Zimbabweans abroad. Ryhove (2013, p. 4) comments that for Zimbabweans in diaspora:

[although]...the diaspora does not directly pay tax to the state, remittances sent to relatives at home (which get taxed through valueadded tax when these relatives purchase commodities) still contribute massively to the economies of such countries. Remittances are indeed a major source of foreign exchange.

Dumaphi Mema, president of the US-based Association of Zimbabweans Based Abroad (AZBA) argues that Zimbabwean citizens should not pay their government in order to vote. Mr Kimenyi, another Zimbabwean citizen resident in Washington, USA argued that enabling Zimbabwean citizens in the diaspora to vote from their adopted countries would 'work against Mugabe and he would see it as direct opposition' (ibid.).

Since 2018 when the MDC Alliance was defeated by Zanu-PF, opposition political parties have fragmented into smaller inconsequential splinter parties, unable to speak with one voice on the matter of the diaspora vote ahead of the 2023 general elections. This political development in Zimbabwe appears to go against normative thinking which is that smaller parties are likely to mobilise around each other in order to defeat a political party deemed hegemonic. Braun and Gratschew et al. (2007, p. 8), argue in this direction when they point out that:

It is also the case that international migrants are a potentially important political force whose votes can in many cases significantly affect 
election results. Political parties, sitting governments and oppositions are therefore likely to have different views on participation in the elections. If large groups of citizens have left the country for political reasons, it can be assumed that the ruling party will not favour extending voting rights to these groups.

When Romanian President Traian Basescu was re-elected in 2009, he garnered a higher share of diasporic votes after promising more democratic reforms, concrete economic freedom, and less corruption (Burean 2011). This is in stark contrast to Zanu-PF's track record that shows electoral fraud, voter harassment and shooting of people who protest against election rigging. The Bertelsmann Stiftung country report on Zimbabwe (2018, p. 38) claims than Zanu-PF's habit of orchestrating electoral violence among political opponents shows that the 'Zimbabwean government is not efficient in the use of human, financial and organisational resources'. In contrast, Reilly (1989) views political inefficiency as willed by dominant elites who use it as a new model misgovernance to entrench their politico-economic interests. The gravity of this view is that as things now stand, Zimbabwean citizens living abroad appear not to be a priority for either Zanu-PF or MDC-T and its allies.

\section{DISCUSSION AND ANALYSIS}

Implications of Denying Voting Rights to Zimbabwean Citizens in the Diaspora

The legal framework of the Zimbabwe Constitution 'contains several gaps' (ZESN 2018, p. 6). The main gap that negatively impacts the possibility of participation in the political life of the country by Zimbabweans in the diaspora, is the apparent silence of Zimbabwe's Constitution on the provision that might have enabled and then encouraged the diaspora to vote from abroad. Other critical gaps in the Zimbabwe Constitution are those requirements that limit local citizens to vote only in the constituency in which they are registered. A requirement in the Constitution that people have to vote from their registered constituencies undermines the voting process through apathy. Many Zimbabweans are reeling under economic hardships and COVID-19 intensifies this suffering (Gumbu 2020). This means that local citizens who have moved from the constituencies where they were registered would not be able to vote in the new constituencies where they had settled. Voter absenteeism benefits the establishment because public officials from the ruling party can use the state machinery to monitor and limit polling stations in those areas where opposition parties might do well. 
Regional and international organisations such as SADC and the African Union promote granting voting rights to African citizens but without distinguishing between local citizens and those working and living abroad (Sarkin 2009). The African Union's rhetoric on its responsibility to protect Africans from injustice and electoral violence is on paper (Yihdego 2011). In addition, AU member states have the power to enforce municipal authority within their territorial borders, and this enables Zimbabwe to delay the voting process and disenfranchise her citizens in the diaspora. Zimbabwean citizens working abroad remit finances to their families and also use their money to invest in the country. Today, most Zimbabwean families depend on remittances from sons, daughters, husbands and wives to sustain their livelihoods. The refusal by the Zimbabwean authorities to grant this category of Zimbabwean citizens abroad the right to exercise their right to vote from their adopted countries is intended to slow down the wheels of democratic and electoral reform in the country. This benefits elites but undermines the potential economic growth that Zimbabwe might register, had these citizens been assured of retaining their political rights in the country. An argument can be made to the effect that had Zanu-PF authorities in Harare openly assured Zimbabwean citizens abroad that their economic interests in Zimbabwe would be politically and legally protected and promoted through exercising their right to vote in national elections, Zimbabwe could benefit economically, culturally, technically and politically. This assumption was tested during the GNU of Mugabe and Tsvangirai.

Maseko's (2010) study shows that transnational identities emerge from the constant trafficking of cultural resources experienced elsewhere, and that these can be grafted onto the political cultures of the country of origin. Such cultural resources often have a dynamising effect that can change or promote the spirit of adopting or developing new electoral reforms in places where electoral provisions lag behind human experiences. As has been observed in the court judgment in Richter V Minister for Home Affairs in South Africa, the significance of the cultural benefits of allowing non-resident citizens to vote in national elections derive from the fact that:

we now live in a global economy which provides opportunities to South African citizens and citizens from other countries to study and work in countries other than their own. The experience that they gain will enrich our society when they return, and will no doubt enrich, too, a sense of a shared global citizens...to an extent that citizens engaged in such pursuit want to take the trouble to participate in elections while abroad, it is an expression both of their continued commitment to our country and civic mindedness from which our democracy will benefit. 
It is evident from the discussion above that the refusal to grant Zimbabwean citizens the right to vote tends to undermine the image of SADC as a dynamic regional block with the potential to promote the rule of law and deepen democratic practices. These include the participation of the region's citizens to vote and shape their destinies from abroad or locally. Nyawo (2019, p. 411) referring to the Country Reports on Human Rights Practices of 2017, observed that in the aftermath of the 2018 elections:

[the] most significant human rights issues included governmenttargeted abductions, arrest, torture, abuse and harassment, harsh prison conditions, executive political influence on and interference in the judiciary, restrictions on freedoms of expression, press, assembly, association, and movement and government corruption.

The picture of post-election violence painted above transmits a foreboding sense that if steps are not taken to reform Zimbabwe's electoral law, both local citizens and Zimbabweans working and living abroad will be deprived of their voice to participate positively in the culture of democracy in Zimbabwe in the forthcoming 2023 elections. If the Zimbabwean authorities can kill local voters, as happened on 1 August 2018, what will become of Zimbabwean citizens living and working abroad who want to voice their concerns through a peaceful vote? In raising these difficult questions ahead of the 2023 general elections, this current study contributes to widespread concern, for Zimbabwe currently has a military-led government (Asuelime 2018). In other words, Zimbabweans now need to put the issue of the voting rights of Zimbabweans in the diaspora at the centre of the country's debate. Recent scholarship acknowledges the fact that citizen identities have become transnational, which means that citizens of one country who are working and living in another country should be able to cast their votes from their host countries. This current study is an unapologetic contribution towards that debate ahead of the 2023 national elections in Zimbabwe.

\section{RECOMMENDATIONS}

Local citizens, Zimbabweans living abroad, civic organisations, and some democratic voices within Zanu-PF and opposition political parties, should foreground Zimbabwe's diaspora vote as the main agenda or talking point for the 2023 general elections. The study recommends that democratic forces both inside and outside the country should engage in serious dialogue with the Mnangagwa government on the inclusion of Zimbabwe's diaspora vote, as follows: 
- There must be a solid coalition of people in the diaspora willing to struggle for the Zimbabwe diaspora vote to be realised.

- Democratic voices need to use the Political Actors Dialogue platform to debate with Zanu-PF the inclusion of the Zimbabwean diaspora vote.

- Zimbabweans in the diaspora need to undertake critical research on models of diaspora voting and how they are practiced regionally and internationally.

- The political opposition in Zimbabwe should make the Zimbabwe diaspora vote the talking point in anticipation of the 2023 general elections.

- SADC and the AU are well placed to promote voter education for Africans in the diaspora (Earnest 2004).

- Zimbabwe's legislation on electoral reforms must accord with those of progressive countries in the EU, US, Africa and the SADC region.

\section{CONCLUSION}

The main aim of this study is to offer a critique of Zimbabwe's electoral laws. It demonstrates that the Zimbabwean Constitution confines external voting to diplomats, civil servants and the armed forces. Bounded citizenship is discriminatory and undermines the prospects of embracing expansive citizenship, and recent scholarship acknowledges the significance of transitional citizen identities. The discussion shows that in many EU and some African countries, citizens of one country who are resident and live in another country are enabled by legislation to vote in the national elections of their original countries. This is a progressive trend which is promoted on paper by the AU and SADC. Senegal, South Africa and Botswana represent progressive legal and institutional frameworks that allow citizens working abroad to vote in their country of origin. However, Lesotho, Uganda and Zimbabwe are among the African countries which have regressive/restrictive electoral laws with a negative impact on their citizens abroad.

This current study sought to question why Zimbabwe has not followed other progressive SADC states in enabling Zimbabwean citizens working and living abroad to vote in the country's elections in 2018. This is a serious question because Zimbabwe lags behind in reforming its electoral laws, especially those that might enable diaspora voting. The Constitution of Zimbabwe emphasises bounded citizenship in which voting rights are granted only to citizens domiciled in the territory. Even on this point, the Constitution of Zimbabwe allows citizens in the territory the right to vote 'subject to this constitution'. The requirement of 
residence, of identity cards and of addresses where citizens in the territory live suggests that the exercise of the right to vote is limited.

More than 3 million Zimbabwean citizens living and working abroad would like to vote in the country's elections but are not yet able to do so. The main reason why they are denied the right to vote is in the 2018 judgement of Shumba and Others Vs the Ministry of Justice, Legal and Parliamentary Affairs and Others. This study seeks to contribute to the growing scholarship on citizen rights and voting rights by identifying the gaps in Zimbabwe's Constitution. The study argues that there are demonstrable facts suggesting that both ideological and political expediency are used by Zimbabwean authorities to deny her citizens the right to vote from abroad. Politicians belonging to dominant political parties are motivated by the desire to remain in power, and it is not beyond the bounds of possibility that these politicians might amend the constitution to safeguard their own political interests.

The study offered tentative recommendations, some realistic and others controversial. For example, if it is true that President Mnangagwa took a bold step in promulgating Statutory Instrument 62 of 2020 to negotiate with former white settlers on the land issue, this study remains optimistic that if approached in a different way, he might amend the Constitution to enable Zimbabwean diaspora voting. He is said to have pointed out that in principle he agrees with idea of allowing Zimbabwean citizens to vote from abroad (Mumbere 2018). For as long as Zimbabwean 'citizens in the diaspora still continue to engage in the socio-economic well-being of their country, they should enjoy all rights owed to the country's citizens' (Ryhove 2013, p. 4). Looking forward to the 2023 general elections, political representatives of the Zimbabwean diaspora should make this the core election issue and point of mobilisation.

Voting from abroad introduces the concept of flexible citizenship, which recognises the different levels at which the right to vote shall be exercised, 'from the most global to the most local or autochthonous, from the ethnic to the most civic, from the individual to the collective' (Ryhove, p. 9). This study claims that this is the time to debate the scope, content and legal implications of expanding democratic spaces for Zimbabwe's diaspora to vote freely.

\section{REFERENCES}

Abadura, L, Fahrenhorst, B \& Zelezny, F 2014, 'Untapped Potential: Engaging Basotho Diasporas'. In South for National Development, Eco-Development Research Report, Society for International Development Research and Planning, Ltd., International Organisation for Migration, Brussels. 
African Union 2007, 'African Charter for Democracy, Elections and Governance', Adopted by the Eight Ordinary Session of the Assembly, Held in Addis Ababa, Ethiopia, 30 January.

African Commission on Human Rights 2015, The Right to Nationality in Africa, African Commission on the Human and people's Rights, Gambia.

Akwei, I 2017, 'Kenya Decides 2017: Uhuru Kenyatta Leads in Diaspora votes', Africa News 11 August. Available at https:www.Africanews.co/11/2017/08/ [Accessed 11 May 2021].

Asuelime, LE 2018, 'A Coup or not a Coup: that is the question in Zimbabwe', Journal of African Foreign Affairs, vol. 5, no. 1, pp. 5-24.

Australian Government, Department of Foreign Affairs and Trade 2019, DFAT Country Information Report Zimbabwe, 18 December.

Brand LA 2010, 'Authoritarian States and Voting from Abroad: North African Experiences', Comparative Politics, vol. 43, no. 1, pp. 81-99.

Braun, N, Gratschew, M, Ellis, A, Morales, I \& Navarro, C 2007, Voting from Abroad: The International IDEA Handbook, International Institute for Democracy and Electoral Assistance, IDEA, Mexico.

Bankowski Z, \& Christodoulidis, E 1999, 'Citizenship Bounded and Citizenship Unbounded', In K Dannreuther \& R Hutchings (eds), Cosmopolitan citizenship, Palgrave Macmillan, UK.

Bertelsmann Stiftung, BTI, 2018 Country Report - Zimbabwe, Bertelsmann Stiftung, Gutersloh.

Baubouk, R 2005, 'Expansive Citizenship: Voting beyond Territory and Membership,' Political Science and Politics, vol. 38, no. 4, pp. 683-687.

Burean, T 2011, 'Political participation by the Romanian Diaspora', In PE Sum \& RF King (eds), Romania Under Basescu: Aspirations, Achievements and Frustrations during His First Presidential Term, Lexington Books, Lanham.

Chari TJ 2017, 'Electoral Violence and Its Instrumental Logic: Mapping Press Discourse on Violence During Parliamentary and Presidential Elections in Zimbabwe,' Journal of African Elections, vol 16, no 1, pp. 72-96.

Chigara, BA 2018, 'Operation Restore Legacy Renders Southern African Community Development (SADC) Constitutionalism Suspect in the Coup d'état that was not a Coup,' Oregon Review of International Law, vol. 20, pp. 173-218.

Chimedza, TL 2008, ‘Bulldozers Always Come: “Maggots”, Citizens and Governance in Contemporary Zimbabwe'. In MT Vambe (ed), The Hidden Dimensions of Operation Murambatsvina in Zimbabwe, Weaver Press, Harare.

Constitution of Zimbabwe: Amendment (No. 20) ACT 2013, Fidelity Printers and Refiners, Harare, pp. 1-151.

Earnest, DC 2004, 'Voting Rights for Resident Aliens: Nationalism, Postnationalism and Sovereignty in an era of Mass Migration', PhD Dissertation, Columbia College of Arts and Sciences, George Washington University, Washington, D.C. 
Esman, M J 1992, 'The political fallout of international migration', Diaspora, vol. 2, no. 1, pp. 3-41.

European Commission 2005, Report of the Commission of the European Communities on granting a derogation pursuant to article 19 (1) of the EC Treaty, presented under article 12 (4) of Directive 94/80 Econ the right to vote and stand as a candidate in municipal elections, European Commission, Brussels.

Frank v Canada 2020

Goredema, D 2019, 'The Dilemma of the Zimbabwe Electoral Commission in the July 312018 Harmonised Elections', In MT Vambe \& W Gadzikwa (eds), ZIMBABWE: The Mighty Fall of a Type of Nation-State, Africa Institute for Culture, Peace, Dialogue and Tolerance Studies, Harare.

Gumbu, YL 2020, 'COVID-19 and its impact on Zimbabwean Immigrants in South Africa', Modern Diplomacy, pp. 1-7.

Krieger, N 1995, Zimbabwe's Guerrilla War: Peasants Voices, Baobab Books, Harare.

Kuhlmann, J 2010, Political Activism of the Zimbabwe Diaspora: Opportunities for, and challenges to transnational mobilization, Graduate Centre of Humanities and Social Sciences of the Research Academy, Leipzig.

Lacy, B 2007, 'Host Countries issues', In Voting from Abroad: The International IDEA handbook, Instistuto Federal Electoral, Mexico, pp. 137-148.

Lupoli, P 2007, 'Enabling Displaced and Expatriate People to Vote and the Role of the International Community', In Voting from Abroad: The International IDEA handbook, Instistuto Federal Electoral, Mexico.

Madziva, R, McGrath, S, \& Thondhlana, J 2013, 'Zimbabwean graduate migrants are more than British Bottom Cleaners', https: //theconversation.com/Zimbabwemigrants-are-more- than... [Accessed, 27/02/2021]

Mangongera C \& Hlatshwayo, GK 2020, 'The Challenges of Social Movements in Post-Mugabe Zimbabwe', January 22, Available <http//usi.org/ publications/2020/01/challenges-social-movments-in-post-mugabeZimbabwe> pp. 1 [Accessed 23 April 2021]

Makumbe, J 2009, 'The Impact of Democracy in Zimbabwe: Assessing social, political, and economic developments since the dawn of democracy', University of Zimbabwe Publications/Centre for Policy Studies, Harare.

Mamdani, M 2018, Citizen and Subject: Contemporary Africa and the Legacy of Late Colonialism, Princeton University Press, Princeton.

Mandal, R 2003, 'Legal and protection Policy: Research Series Political Rights of Refugees', UNHCR, Geneva. Available at http://www.uhcr.org [Accessed on 23 April 2021]

Maseko, T 2010, 'Voting Rights for Nationals of the Southern African Development Community countries living in member states', International Journal of African Renaissance Studies, Multi- Inter, - Transdisciplinarity, vol. 5, no 2, pp. 242-254. 
Mawadza, A \& Murithi, T 2011, (eds), Zimbabwe in Transition: A View from Within, Jacana, Johannesburg.

Mavungu, ME 2013, 'Stay in Power What-ever it Takes: Fraud and Repression in the 2011 in the Democratic Republic of Congo,' Journal of African Elections, vol. 12 , no. 3, pp. 25-50.

MINDS High Level Dialogue Series Report, 2018. ‘Reigniting Hope for democracy Beyond Elections in Zimbabwe', Mandela Institute for Development Studies, Johannesburg, pp. 1-60.

Moyo, Z, 2013, 'The Right to vote: Where do Citizens in the diaspora stand?', In On Africa IOA, pp. 1-8.

Mumbere, D 2018, 'Mnangagwa to consider voting rights for Zimbabweans in the diaspora', Africanews, 25 September. available at https://www.Africanews. com/2018/09/25mnangangwa-to-consider-voting-rights-for-Zimbabweans -in-diaspora, [Accessed 25/02/2021]

New York Amsterdam News 2018, 'No Voting Rights for the Diaspora, Zimbabwe Court Rules. Available at < http//www.Charlesstonchronicle.net/2018/03/22/ no-rights-fo-dias...> p. 2 [Accessed 8/9/2020]

Muzondidya, J 2011, 'The Zimbabwe Diaspora: Opportunities and challenges for engagement in Zimbabwe's pollitical development and economic transformation', In A Mawadza \& T Murithi, T (eds), Zimbabwe in Transition: A View from Within, Jacana, Johannesburg.

Nyamnjoh, F 2007, 'From Bounded to Flexible Citizenship to: Lessons from Africa', Citizen Studies, vol. 11, issue 1, http://dx.org/101/080/13621020601099880, pp. 1-11 [Accessed 27/02/2021]

Nyawo, ZV 2019, 'Zimbabwe's Human Rights Record Since 17 November 2017', In MT Vambe \& W Gadzikwa (eds), ZIMBABWE: The Mighty Fall of a Type of Nation-State, Africa Institute for Culture, Peace, Dialogue and Tolerance Studies, Harare.

News 24 2018, 'There will never be a coup again in Zimbabwe, says VP Chiwenga', 30 June. Available at $<$ https://www.news 24./com/news 24/Africa/ Zimbabwe// there-will-never-be-a-coup-again-in-Zimbabwe...> [Accessed 27 February 2021]

Nohlen, D \& Grotz, F 2007, 'The Legal Framework and an Overview of Legislation', In Voting from Abroad: The International IDEA handbook, Instistuto Federal Electoral, Mexico.

Oliver, G 2009, 'Expats oppose tax in exchange for voting', The New Humanitarian, 21 December, Available at https://www.thenewhumanitarian.org/fr/ node/247556... [Accessed 20 May 2021]

Odok, EG 2019, 'Normative and Historical Performances of the 2017 Coup d'état in Zimbabwe: Agency in ZAPU and ZANU Power Struggles', In MT 
Vambe \& W Gadzikwa (eds) ZIMBABWE: The Mighty Fall of a Type of NationState, Africa Institute for Culture, Peace, Dialogue and Tolerance Studies, Harare.

Organisation of African Unity 1981, African Charter on Human and People's Rights, Available at $<$ http://ouint/en/treaties/African-Chater-on-Human-andPeople's-Rights.... [ [Accessed 23 April 2021]

Pasura, D 2008, 'A Fractured Diaspora: strategies and identities among Zimbabweans in Britain', Unpublished Thesis, University of Warwick, Coventry.

Reilly, W 1989, 'Political Influences on Management Training in Africa', Management, Education and Development, vol. 20, no. 3, pp. 176-190.

Richter v Minister for Home Affairs and Others 2009 (with the Democratic Alliance and Others intervening, and with Afriforum and Another as Amici Curiae) (CCT03/09:CCT09/09 [2009] ZACC 3 (12 March 2009)

Ryhove, S 2013, 'The Right to Vote: Where do citizens in the Diaspora stand' Part I, Polity, 8 April. Available at $<$ https://www.polity.org.za/article/the-right-tovote-where-do-citizens-in-the diaspora-stand-part1...> [Accessed 27 February 2021].

Sarkin, J 2009, ‘The Role of the United Nations, The African Union and Africa's Subregional Organisations in Dealing with Africa's Human Rights Problems: Connecting Humanitarian Intervention and the Responsibility to Protect', Journal of African Law, vol 53, no 1, pp.1-33.

Saurombe, A 2019, 'The Constitutionality of the fall of Mugabe in Zimbabwe and the Litmus test for the SADC region', In MT Vambe \& W Gadzikwa (eds), ZIMBABWE: The Mighty Fall of a Type of Nation-State, Africa Institute for Culture, Peace, Dialogue and Tolerance Studies, Harare.

Tungwarara, O 2007, 'Zimbabwe: Highly Restrictive Provisions', In Voting from Abroad: The International IDEA handbook, Instistuto Federal Electoral, Mexico, pp. 56-58.

United Nations 2020, 'Expats oppose tax in exchange for voting', https://stop.un.org/ rights-permissions. [Accessed 8/9/2020]

Vambe MT 2019, 'Zimbabwe Diaspora Electoral Dream deferred: The Politics of Arrested Democracy in Zimbabwe in 2018', In MT Vambe \& W Gadzikwa (eds), ZIMBABWE: The Mighty Fall of a Type of Nation-State, Africa Institute for Culture, Peace, Dialogue and Tolerance Studies, Harare.

Yihdego, Z 2011, 'The African Union, Founding Principles, Frameworks and Prospects', European Law Journal, vol. 17, no. 5, pp. 568-594.

Zimbabwe Election Support Network 2018, Position Paper, Diaspora Voting. Available at <https://www.zesn.org.zw/wp-content/uploads/2019//10/zesn-position> p.1 [Accessed: 25/02/2021] 